УДК 371. 004. 33

Кобися Володимир Михайлович кандидат педагогічних наук, доцент

Вінницький державний педагогічний університет імені Михайла Коцюбинського, м. Вінниця, Україна ORCID ID 0000-0001-8865-2916

vkobysa@ukr.net

Зарічанська Наталія Володимирівна

кандидат педагогічних наук, старший викладач

Вінницький державний педагогічний університет імені Михайла Коцюбинського, м. Вінниця, Україна ORCID ID 0000-0002-5636-1900

natazarvin@gmail.com

Бобліснко Олена Павлівна

кандидат педагогічних наук, старший викладач

Вінницький національний медичний університет ім. М. І. Пирогова, м. Вінниця, Україна

ORCID ID 0000-0002-3408-9328

elenaboblienko@gmail.com

\title{
СТВОРЕННЯ І ВИКОРИСТАННЯ ЕЛЕКТРОННОГО ПІДУЧНИКА ДЛЯ ВИВЧЕННЯ ІНОЗЕМНОЇ МОВИ
}

\begin{abstract}
Анотація. У статті розглянуто можливості створення електронного навчального підручника на основі хмарних технологій i використання його для вивчення іноземної мови, проаналізовано структуру i зміст електронного підручника, описано використання елементів візуалізації навчального матеріалу з використанням презентацій, відеоматеріалів, графічних елементів, організаційних діаграм тощо, описано переваги використання інтерактивних навчальних вправ 3 англійської мови, розроблених з використанням хмарних технологій, охарактеризовано переваги створення та використання close-тестів для перевірки якості формування теоретичних знань і практичних умінь учнів під час вивчення іноземної мови, наведено структуру електронного підручника та приклади інтерактивних вправ, розроблених за змістом підручника.
\end{abstract}

Ключові слова: електронний підручник; англійська мова; інтерактивна вправа; відеоматеріал; сlose-тест.

\section{1. ВСТУП}

Постановка проблеми. В умовах розвитку сучасного суспільства інформаційні технології глибоко проникають у життя людей. Вони дуже швидко перетворилися на життєво-важливий стимул розвитку не лише світової економіки, а й інших сфер людської діяльності. Нині важко знайти галузь, у якій не використовуються інформаційні технології. Застосування інформаційних технологій у науковій діяльності й у галузі освіти складно переоцінити. Важко уявити собі навчальний заклад, у якому б не було комп'ютерного класу. Існує маса електронних бібліотек, скористатися якими можна не виходячи з дому, що значно полегшує процес навчання і самоосвіти. Наразі, інформаційні технології сприяють розвитку наукових знань. Щодня збільшується кількість програм та додатків, що сприяють полегшенню роботи вчителя та кращому засвоєнню нової інформації учнями. Особливої уваги потребує вивчення іноземних мов. Оскільки ми живемо у час глобального технологічного розвитку і мешканці нашої країни отримали можливість безвізового перетину кордонів з країнами Свропейського союзу, то добре знання іноземної мови, особливо англійської, $є$ просто необхідним, адже англійська мова - мова спілкування мільярдів людей. Усім відомо, що секрет успішного оволодіння іноземною мовою полягає в постійній практиці та наполегливій 
праці. Проаналізувавши певні дослідження, хочеться наголосити на тому, що іноземна мова вивчається через спілкування; заняття починаються зі спілкування, а не із засвоєння граматичних правил; навчання іншомовного спілкування проходить у формі рольової гри; ефективнішим є мультимедійний підхід, заснований на використанні кількох взаємодоповнюючих інформаційних технологій [1, с. 35]. Усвідомити це дорослій людині набагато легше, ніж учням у школі, тому прості методи зацікавлення учня підручником уже недієві. У час бурхливого розвитку комп'ютерних технологій потрібно докласти максимум зусиль i зробити навіть звичайний урок цікавим i продуктивним.

Аналіз останніх досліджень і публікацій. Теоретичним і практичним аспектам проблеми комп'ютеризації освіти присвячені роботи Б. Гершунського, А. Сршова, А. Короткова, В. Лецко, О. Локтюшиної, С. Машбиця, В. Монахова, Н. Морзе, В. Рубцова, П. Підкасистого, О. Тищенко, В. Долматова та ін. Можливості комп'ютерної комунікації у вищих навчальних закладах щодо змін змісту навчання розкривають М. Алексєєв, С. Григорьєв, Б. Гершунський, Н. Женов, А. Оголь, А. Петров. Проте науковці переважно акцентують увагу на властивостях комп'ютерних технологій як універсальних засобів обробки інформації. Дослідження 3. Джаліашвілі, В. Колесникова, А. Крицького, Г. Чусавітіної відзначають окремі комунікативні властивості комп'ютерної освіти, особливості комп'ютерних навчальних систем щодо побудови навчання у режимі діалогу. Реалізації можливостей ресурсів телекомунікаційних мереж як глобального середовища безперервної освіти присвячені роботи С. Богданової, С. Коракозова, С. Полат та ін. Окремі аспекти інформатизації вивчення іноземних мов розглядалися М. Акоповою, О. Бігич, М. Бухаркіною, О. Дмитрєвою, Є. Носенко, І. Павловою, Є. Полат та ін. Проте грунтовних досліджень 3 визначення й реалізації можливостей використання електронного підручника для вивчення іноземної мови на основі хмарних технологій не проводилось.

Мета статті - показати можливості створення і використання в навчальному процесі електронного підручника для вивчення іноземної мови на основі хмарних технологій.

\section{2. РЕЗУЛЬТАТИ ДОСЛІДЖЕННЯ}

Інтерактивні засоби навчання $є$ універсальними i, як зазначає I. Дичківська, можуть бути використані на різних етапах уроку: під час мотивації як постановка проблеми перед вивченням нового матеріалу, у процесі пояснення нового матеріалу як ілюстрації, під час закріплення й узагальнення знань, для контролю та самоконтролю знань [2, с. 56]. Інтерактивні засоби навчання повинні відповідати системі психологічних, дидактичних, методичних вимог. Так, наприклад, під час уроків повторення й узагальнення інтегруються дидактичні можливості, a, отже, й методичні варіанти використання інтерактивних засобів, що мають різне дидактичне призначення. Це може бути джерелом нової навчальної інформації, матеріалом для виконання самостійної роботи чи перевірки знань учнів, ілюстрацією до вже відомого матеріалу [3, с. 87].

Одним із способів підвищення інтересу учнів до вивчення іноземної мови $€$ спроба оживити друкований підручник, зробити його більш сучасним, електронним. Візьмемо для прикладу звичайний підручник 3 англійської мови для 10 класу О. Д. Карп'юк, насичений різноманітною кількістю вправ: для засвоєння граматичного матеріалу, вивчення нових слів, тем для обговорення в класі та закріплення нового матеріалу, поділений на вісім змістових розділів, вивчення яких необхідне як для повсякденного спілкування, так і для розширення світогляду учня. Кожен розділ має 
збірки різноманітних вправ для обговорення й виконання в класі, вдома та самостійного опрацювання. Підручник містить додатковий граматичний матеріал у вигляді таблиць і текстів, які учень може опрацювати самостійно або використати для закріплення матеріалу вивченого в класі.

Звичайно, така структура підручника є просто необхідною для вивчення мови, але використання додаткових інтерактивних засобів навчання може допомогти сучасному вчителю привернути увагу учня до певного матеріалу і в той же час подати цей матеріал у цікавішій формі та зробити його доступнішим для розуміння учнями. 3 використанням сучасних інформаційних технологій текст підручника можна доповнити мультимедійними матеріалами, які може розробити вчитель, учні, або можна знайти в мережі Інтернет. Чудовим засобом для цього є програма Microsoft OneNote - pecypc для створення швидких заміток i організації особистої інформації 3 ієрархічною організацією записів, що входить до складу пакету Microsoft Office. 32014 програма стала безкоштовною, іiі можна завантажити окремо із сайту Microsoft, iснує як локальна, так і он-лайн версія програмного засобу.

Основою електронного підручника є звичайний електронний варіант навчального підручника О. Д. Карп’юк «Англійська мова», який можна знайти на сайті Міністерства освіти i науки України. Розроблений і апробований нами електронний підручник розташовано на 8 закладках, кожна 3 яких містить матеріал відповідного розділу друкованого підручника (рис. 1). Кожен розділ містить значну кількість дидактичних матеріалів, які вбудовано в текст підручника і позначено спеціальними позначками.

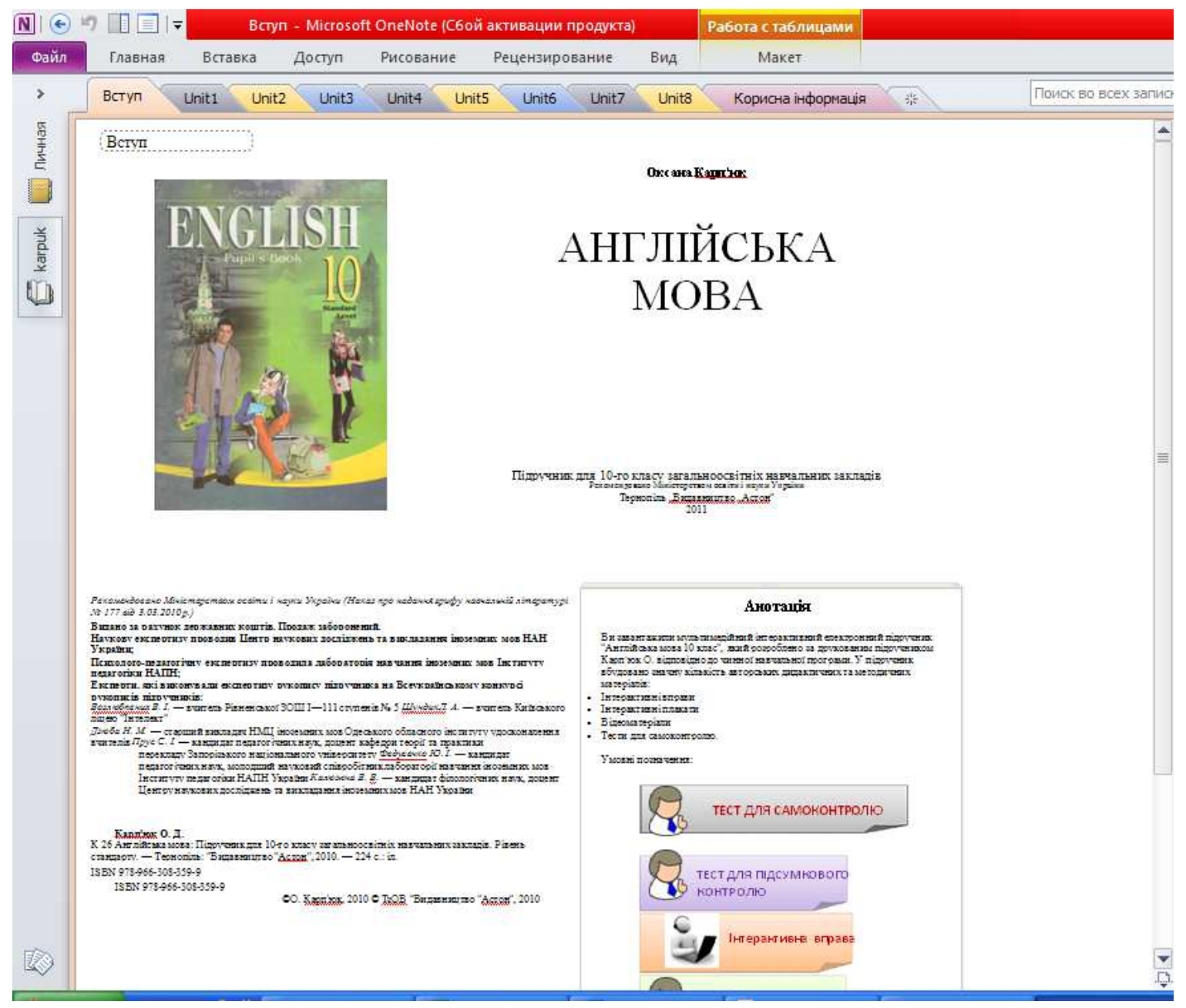

Рис. 1. Загальний вигляд структури електронного підручника 
До навчальних вправ засобами Microsoft OneNote приєднано тематичні презентації, розроблені за допомогою Microsoft Power Point, що містять достатню для пояснення кількість схем, малюнків, фото, відео тощо. За допомогою таких презентації нова інформація сприймається учнями значно краще i швидше. Використання візуальних елементів значно підвищує ефективність запам'ятовування навчального матеріалу та сприяє його систематизації. Під час апробації електронного підручника у навчальних групах якість теоретичних знань учнів збільшилася на 12-15\%.

Унікальною особливістю електронного підручника $є$ наявність інтерактивних вправ, які розроблені за допомогою он-лайн pecypcy LearningApps. Ці вправи використовують різноманітні навчальні методики: часова шкала, співставлення, вписування, ранжування, упорядкування, тестові завдання на вибір однієї чи кількох правильних відповідей. Важливо відзначити, що правильність виконання завдань перевіряється миттєво. Усі розроблені вправи згенеровані засобами Інтернет-сервісу LearningApps у локальні архіви, що містять веб-сторінки з використанням сценаріїв та аплетів, які можуть використовуватися у навчальному процесі як $з$ допомогою мережі, так і локально без доступу до неї (рис. 2).

Основна ідея інтерактивних завдань полягає в тому, що учні можуть перевірити i закріпити свої знання в ігровій формі, що сприяе формуванню пізнавального інтересу до вивчення іноземної мови. Такого роду вправи можна застосовувати на будь-якому етапі уроку, особливо на початку з метою активізації їхньої діяльності або наприкінці, коли учні втомлені, а також для самостійного вивчення матеріалу. Попри це, за допомогою цих вправ можна налагоджувати процес індивідуалізації і диференціації навчання, адже в будь-якому класі завжди є учні, які швидше засвоюють інформацію i, щоб вони не сумували, можна запропонувати їм виконати додаткові завдання. Використання інтерактивних вправ під час апробації електронного підручника сприяло підвищенню якості виконання практичних завдань на 15-22\%.

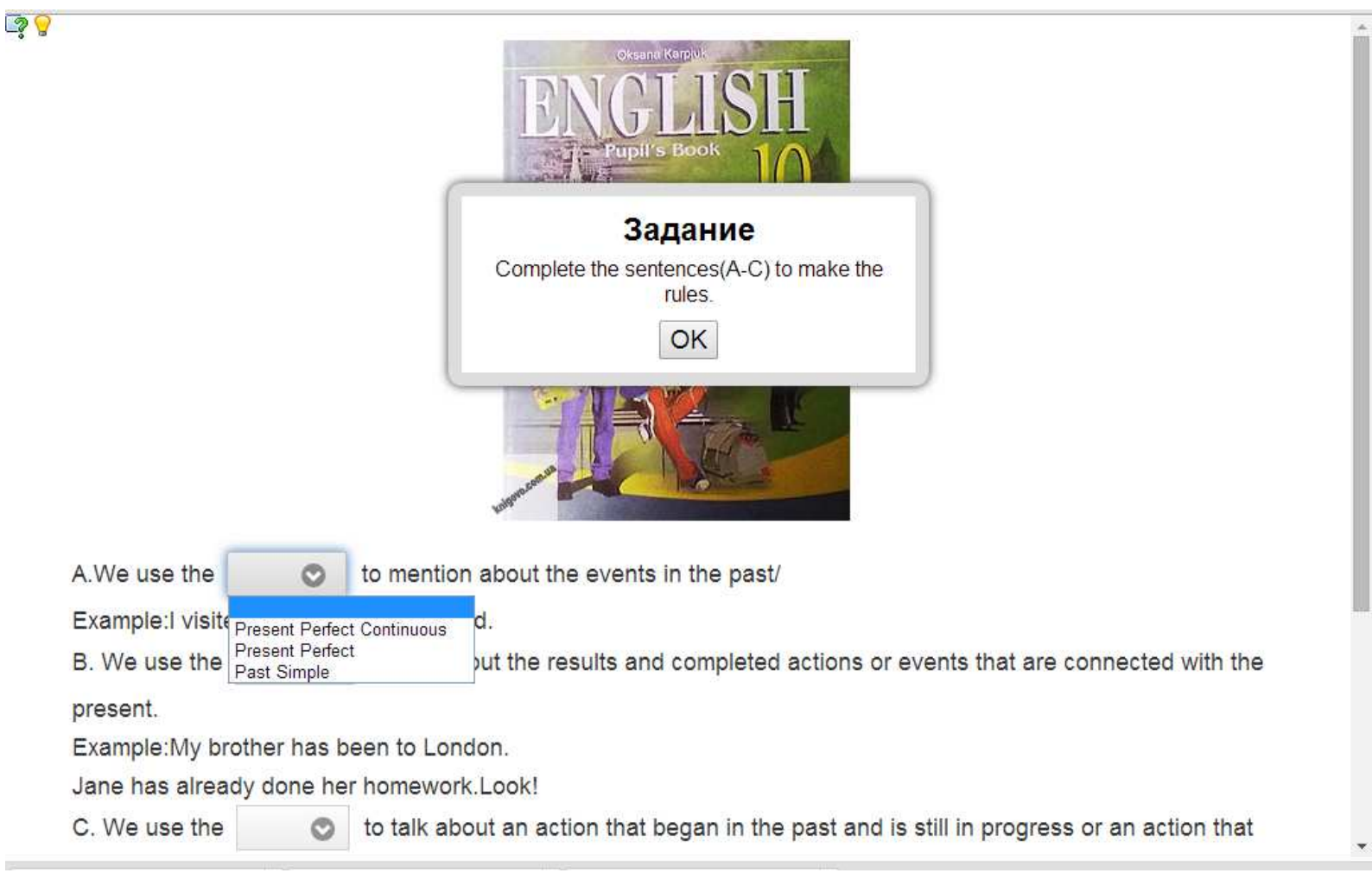

Рис. 2. Фрагмент інтерактивної вправи 
Ще одним додатком до друкованого підручника $є$ значна кількість тематичних відеоматеріалів, створених учителем та учнями 3 використанням різноманітного технічного і програмного забезпечення. Переглядаючи такі відео, учні можуть не лише дізнатись нові цікаві факти, а й почути правильну британську вимову, а для вивчення англійської мови і формування артикуляційних навичок учнів це дуже важливо.

Варто відзначити способи вирішення питання проведення моніторингу навчальної діяльності 3 використанням комп'ютерно-орієнтованих технологій. Як відомо, традиційні прийоми перевірки знань, навичок й умінь учнів, що застосовуються в навчальному процесі, не завжди відповідають вимогам, що ставляться до раціонального контролю. Пошук ефективніших форм контролю зумовив все зростаючий інтерес до методу тестів.

Суб'єктивність оцінювання знань пов'язана певною мірою 3 недостатньою розробкою методів контролю системи знань. Об'єктивний підхід полягає в тому, що для виявлення наявності знань завжди використовується адекватний інструмент. Сучасна методика пропонує тест як інструмент вимірювання рівня знань, за допомогою якого можна не тільки виявити якість навчання, а й оптимально управляти навчальним процесом [1]. Тестування як метод складається з цілої низки прийомів, серед яких особливої уваги заслуговує так званий close-тест. Цей вид тесту описаний в методичній літературі ще як тест доповнення або тест відновлення. За допомогою close-тестів можна швидко визначити рівень знань, їхню конкретність і глибину, розуміння учнями теми, основних мовознавчих положень.

Close-тест був розроблений і запропонований американським ученим В. Тейлором для визначення того, наскільки важкий той чи інший текст для читання і розуміння, a також наскільки цей текст цікавий для читача. Особливість close-тесту полягає в тому, що ситуація в ньому подається у вигляді зв'язного тексту (як монологу, так і діалогу). Успішність виконання close-тесту знаходиться в прямій залежності від того, наскільки швидко випробуваний може зрозуміти весь текст і відновити зв'язки між подіями або станами персонажів, описаними в тексті. Це, у свою чергу, визначається тим, як добре він володіє лексикою досліджуваної мови, якою мірою у нього розвинена мовна здогадка і як адекватно він розуміє текст кожної конкретної тестової ситуації [3, с. 122].

Close-тести дуже зручні у використанні, мало потребують часу, легко перевіряються. Перед початком тестування опрацьовується теоретичний матеріал, даються настанови вивчити правила, підібрати приклади [3, с.50].

Close-тести використовуються фронтально, а також під час роботи в групах. Учитель обов'язково складає діагностичну карту, щоб бачити, наскільки учні засвоїли теоретичний матеріал.

Методика складання close-тесту не представляє особливих труднощів. Під час розроблення тестових завдань викладач повинен керуватися такими перевіреними на практиці рекомендаціями:

- $\quad$ для основи close-тесту необхідно вибрати уривок прози обсягом не менше 100 і не більше 300-400 слів;

- пропущені слова можуть бути різними частинами мови, різними членами речення;

- уривок прози повинен бути закінченим за змістом;

- виклад фактів або подій повен бути логічно обгрунтований;

- у тексті повинна бути мінімальна кількість власних імен;

- пропущені слова повинні досить легко відновлюватися за рахунок контексту [3, c. 55].

Учні читають відібраний текст про себе двічі. Під час першого читання вони знайомляться 3 його загальним змістом, під час другого - заповнюють пропуски тими 
словами, які вони вважають необхідними для відновлення змісту всього тексту. Учні вписують слова в сlose-тест або записують свої відповіді на спеціальних опитувальних листках. Правильність заповнення пропусків свідчить про точне розуміння тексту у взаємозв'язку лінгвістичних і екстралінгвістичних чинників, представлених у ньому, а також про володіння лексичними одиницями у процесі читання.

Отже, за допомогою close-тесту можна встановити ступінь сформованості навичок читання і рівень володіння учнями лексичною компетентністю у процесі читання.

Реалізувати close-тести можна досить легко 3 використанням сучасних інформаційно-комунікаційних технологій. Для цього слід використати одну з тестових програм.

Close-тест може бути також засобом перевірки розуміння іноземної мови на слух. У цьому випадку він є звуковим записом (у монологічній або діалогічній формі), що транслюється у звичайному темпі за наявності «природних перешкод», роль яких виконують пропущені слова. Психологічним змістом діяльності учнів, що тестуються, під час виконання такого close-тесту $\epsilon$ прогнозування на основі використання надлишкових елементів повідомлення, контекстуальної і лінгвістичної здогадки. Активна внутрішня діяльність навчання 3 відновлення деформованого повідомлення знаходить своє вираження в конкретних результатах: відновлених або не відновлених словах, що свідчить про розуміння або нерозуміння сприйнятого повідомлення.

Під час підготовки close-тесту для контролю аудіювання слід підбирати текст, що містить знайомий учням лексичний матеріал і прості синтаксичні структури. Довжина речень у тексті не повинна перевищувати 13-15 слів. Якщо ж основою close-тесту $\epsilon$ діалог, то кількість учасників діалогу не повинна перевищувати двох осіб.

Такий close-тест будується за таким же принципом, як і описаний вище, однак тут необхідна значна дистанція між пропущеними словами, яка до того ж не носить регулярний характер. У текст-основу можна вносити зміни для того, щоб забезпечити вибір більш відповідного для контролю слова і полегшити для учнів сприйняття тексту на слух.

У процесі підготовки фонограми тексту перший запис мовного повідомлення фіксується на плівці з пропуском певних слів. У другому записі замість пропущених слів слід зробити паузи тривалістю не менше 45 секунд, для того, щоб учні встигли записати свою відповідь під час цих пауз. Попри це, у другому записі має бути особливий звуковий сигнал, для попередження про пропуск (постукування, клацання).

Основними принципами формування тестових завдань $є$ подані далі.

1. Узгодженість засобів і цілей. Принципи формування тестових завдань повинні співпадати з основними принципами формування цілей системи навчального процесу. Том,у перш ніж приступити до розробки тестових завдань, необхідно чітко уявляти, 3 якою метою проводиться тестування і які засоби можна використати для цього.

2. Врахування цілей вивчення дисципліни. Це - цілі зовнішні, внутрішні, стратегічні, тактичні та оперативні, з урахуванням ієрархії цілей як для дисципліни в цілому, так і для розділів і модулів, що ії складають.

3. Здійснення тестування за відносно самостійною частиною навчальної дисципліни. Тестування оправдане, якщо ставиться мета оцінити рівень засвоєння знань й умінь за темою або модулем дисципліни, а не за матеріалом лекції.

4. Визначення ступеня досягнення поставлених цілей. Враховуючи те, що навчання - це елемент освіти і під час вивчення дисципліни завжди ставляться цілі загальноосвітні, загальнонаукові, спеціальні тощо.

5. Відповідність психолого-фізіологічним властивостям пам'яті. Зміст тестового завдання повинен відповідати принципам вибірковості, відгуку пам'яті на запитання, 
відновлення образу, рекурсивності (перетворення), здорового глузду і розуміння, здивування, виправлення помилок, адаптації тощо [3, с. 89].

Розвиток інформаційно-комунікаційних технологій привів до появи на ринку програмного забезпечення значної кількості програм для здійснення тестового контролю знань студентів. Однією 3 програм для створення й роботи 3 тестовими завданнями у комп'ютерній мережі навчального закладу є програмний пакет MyTestX. Програма MyTestX призначена для здійснення мережного моніторингу знань учнів. Вона дозволяє проводити тестування, зберігати його результати та проводити їх аналіз $\mathrm{i}$ дослідження. Програма дозволяє створювати тести 3 довільною кількістю тестових завдань, змінювати вагу кожного завдання, встановлювати часові обмеження на виконання як тесту в цілому, так і кожного окремого тестового завдання. Вона підтримує 9 типів завдань: одна правильна відповідь, кілька правильних відповідей, співставлення, впорядкування, введення числа, введення тексту, вибір частини зображення, переставляння літер, логічні запитання.

Розроблений нами електронний підручник може легко модифікуватися за умови надання прав доступу до нього. Microsoft OneNote дозволяе в будь-якому місці робити текстові й рукописні замітки, вставляти малюнки, а також записувати голосові коментарі, що є дуже важливим під час викладання англійської мови, оскільки з таким підручником за умови надання до нього спільного доступу можна працювати одночасно всім класом. Для зручної навігації і швидкого здійснення пошуку важливих навчальних матеріалів програма пропонує спеціальні мітки - теги, за якими можна налаштувати пошук і навігацію.

Зроблені записи можна надсилати електронною поштою як у форматі HTML, так i у вигляді вкладеного файлу OneNote. У нашому випадку електронний підручник розміщений на хмарному сервісі OneDrive i може використовуватися учнями 3 допомогою будь-якого персонального комп'ютера чи мобільного гаджета незалежно від наявності встановленого на ньому програмного забезпечення, а також існує в onlineверсії як програмне забезпечення для роботи 3 контентом Microsoft OneDrive. Цей підручник не $\epsilon$ примхливим, будь-яка версія програмного продукту коректно працює 3 підручником, тому його можна використовувати незалежно від платформи і наявного програмного забезпечення з різних комп’ютерів і мобільних гаджетів.

Інтерактивний підручник такого формату можна використовувати як у класі, так i для самостійного вивчення навчального матеріалу. Отримавши загальний доступ у Microsoft OneNote учні можуть самостійно робити нотатки i змінювати зміст підручника.

\section{3. ВИСНОВКИ ТА ПЕРСПЕКТИВИ ПОДАЛЬШИХ ДОСЛІДЖЕНЬ}

Отже, електронний підручник «Англійська мова» (10 клас), створений за допомогою програмного забезпечення Microsoft OneNote $\epsilon$ чудовим вдосконаленням друкованого варіанту підручника О. Карп'юк для вивчення англійської мови у 10-х класах загальноосвітніх навчальних закладах, оскільки за його допомогою вчитель може не лише розширити знання учнів, а й зробити свої уроки цікавішими та продуктивнішими.

Запропонована методика навчання англійської мови на основі електронного підручника дозволяє використовувати новітні інформаційні технології для організації й підтримки навчального процесу, підвищувати ефективність навчальної діяльності учнів за рахунок упровадження різноманітних телекомунікаційних засобів, активізувати їх пізнавальні інтереси за рахунок рефлексії їх особистісної діяльності, самоконтролю та 
самоперевірки своїх досягнень, аналізу, аргументації та планування подальших дій, рішень i, нарешті, зміни особистісних успіхів.

Перспективи подальших досліджень вбачаємо у впровадження в навчальний процес сучасних програмних продуктів, мережних сервісів, удосконалення та активного використання технологій хмарних обчислень для розширення можливостей застосування інформаційно-комунікаційних технологій у процесі вивчення іноземної мови i формування в учнів навичок застосування інформаційно-комунікаційних технологій у подальшій навчальній діяльності.

\title{
СПИСОК ВИКОРИСТАНИХ ДЖЕРЕЛ
}

[1] Д. Джонсон, Методы обучения. Обучение в сотрудничестве, Киев, 256 с., 2001.

[2] . Дичківська, Інноваційні педагогічні технології: навчальний посібник, Київ, 351 с.. 2004.

[3] K. Beatty, Teaching and Researching Computer-Assisted Language Learning, Pearson Education Limited, 259 p., 2003.

Матеріал надійшов до редакиї 18.07.2017 p.

\section{СОЗДАНИЕ И ИСПОЛЬЗОВАНИЕ ЭЛЕКТРОННОГО УЧЕБНИКА ДЛЯ ИЗУЧЕНИЯ ИНОСТРАННОГО ЯЗЫКА}

\author{
Кобыся Владимир Михайлович \\ кандидат педагогических наук, доцент \\ Винницкий государственный педагогический университет имени Михаила Коцюбинского, \\ г. Винница, Украина \\ ORCID ID 0000-0001-8865-2916 \\ vkobysa@ukr.net
}

Заричанская Наталья Владимировна

кандидат педагогических наук, старший преподаватель

Винницкий государственный педагогический университет имени Михаила Коцюбинского,

г. Винница, Украина

ORCID ID 0000-0002-5636-1900

natazarvin@gmail.com

\section{Боблиенко Елена Павловна}

кандидат педагогических наук, старший преподаватель

Винницкий национальный медицинский университет им. Н. И. Пирогова, г. Винница, Украина

ORCID ID 0000-0002-3408-9328

elenaboblienko@gmail.com

\begin{abstract}
Аннотация. В статье рассмотрены возможности создания электронного учебника на основе облачных технологий и использования его для изучения иностранного языка, проанализирована структура и содержание электронного учебника, описано использование элементов визуализации учебного материала с использованием презентаций, видеоматериалов, графических элементов, организационных диаграмм и т. п., наведены преимущества использования интерактивных учебных упражнений в процесс се изучения английского языка, разработанных с использованием облачных технологий, охарактеризованы преимущества создания и использования клоуз-тестов для проверки качества формирования теоретических знаний и практических умений учащихся при изучении иностранного языка, приведена структура электронного учебника и примеры интерактивных упражнений, разработанных по содержанию учебника.
\end{abstract}

Ключевые слова: электронный учебник; английский язык; интерактивное упражнение; видеоматериал; клоуз-тест. 


\title{
CREATING AND USING ELECTRONIC TEXTBOOKS FOR LANGUAGE LEARNING
}

\section{Volodymyr M. Kobysia}

$\mathrm{PhD}$ (in Pedagogical Sciences), Associate Professor

Vinnytsia State Pedagogical University named after Mikhail Kotsyubinsky, Vinnytsia, Ukraine ORCID ID 0000-0001-8865-2916

vkobysa@ukr.net

\section{Nataliia V. Zarichanska}

$\mathrm{PhD}$ (in Pedagogical Sciences), Senior Lecturer

Vinnytsia State Pedagogical University named after Mikhail Kotsyubinsky, Vinnytsia, Ukraine

ORCID ID 0000-0002-5636-1900

natazarvin@gmail.com

\section{Olena P. Bobliienko}

$\mathrm{PhD}$ (in Pedagogical Sciences), Senior Lecturer

Vinnytsia National Medical University named after. M.I. Pirogova, Vinnytsia, Ukraine

ORCID ID 0000-0002-3408-9328

elenaboblienko@gmail.com

\begin{abstract}
The article considers the possibilities of creating an electronic textbook on the basis of cloud technologies and its use for studying a foreign language, analyzes the structure and content of the electronic manual, describes the use of elements of visualization of educational material using presentations, video materials, graphic elements, organizational charts, etc., describes the advantages of using interactive English language exercises developed with the use of cloud technologies. The use of cloze tests to test the quality of the formation of theoretical knowledge and practical skills of pupils during the foreign language study, provides an electronic tutorial structure and examples of interactive exercises developed in the content of the textbook.
\end{abstract}

Keywords: electronic manual; English; interactive exercise; video; cloze test.

\section{REFERENCES (TRANSLATED AND TRANSLITERATED)}

[1] D. Dzhonson Methods of training. Learning in Collaboration, Kyiv, 2001. -256 p. (in Russian)

[2] I. Dychkivs'ka Innovative Pedagogical Technologies: Textbook, Kyiv, 2004. 351 p. (in Ukrainian)

[3] K. Beatty Teaching and Researching Computer-Assisted Language Learning, Pearson Education Limited, 2003. 259 p. (in English)

\section{(c) BY-NC-SA}

This work is licensed under Creative Commons Attribution-NonCommercial-ShareAlike 4.0 International License. 